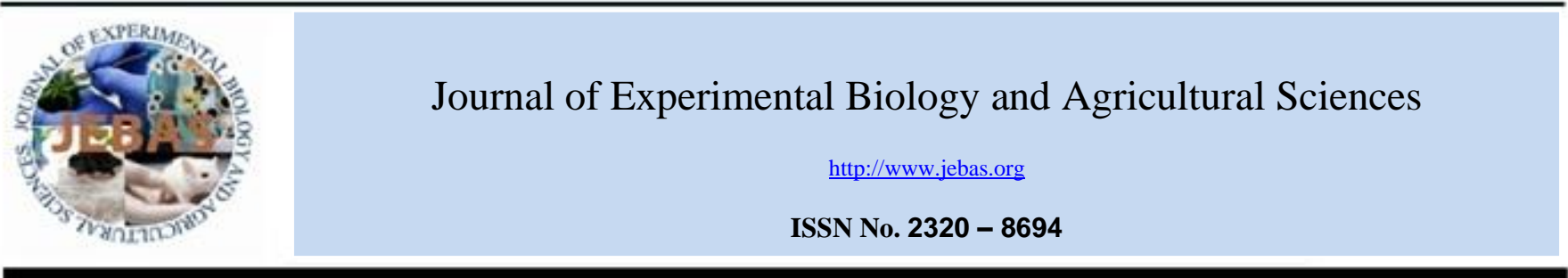

\title{
In silico SCREENING OF Ziziphus spina-christi (L.) Desf. AND Strychnos ligustrine COMPOUNDS AS A PROTEASE INHIBITOR OF SARS-COV-2
}

\author{
Novi Yantih, Uthami Syabillawati, Esti Mulatsari, Wahono Sumaryono
}

Faculty of Pharmacy, Universitas Pancasila, Srengseng Sawah, Jagakarsa, Pasar Minggu, South Jakarta 12640, Indonesia

Received - December 15, 2020; Revision - March 22, 2021; Accepted - May 14, 2021

Available Online - September 08, 2021

DOI: http://dx.doi.org/10.18006/2021.9(Spl-2-ICOPMES_2020).S208.S214

\section{KEYWORDS \\ Molecular docking \\ Coronavirus \\ Ziziphus spina-christi \\ Strychnos ligustrine \\ Jubanine B}

\begin{abstract}
Diseases caused by the coronavirus have become an important concern in early 2020 . The coronavirus is a new type of virus that is included in the SARS-CoV-2 group. One of the possible mechanisms of SARS-CoV-2 inhibition involves protease receptors inhibition. This research was aimed to in silico screening of Ziziphus spina-christi (L.) Desf., and Strychnos ligustrine active ingredients as the main protease inhibitors of SARS-CoV-2 by assessing the ligand-binding affinity in the binding pocket of SARS-CoV-2 main protease protein. The molecular docking method is generally used to predict the inhibitory site and bonds formation. In the current study, some generally used antiviral compounds from the PDB (Protein Data Bank) were also used to compare the affinity strength of the test compound against the protease receptor (code of $5 \mathrm{R} 7 \mathrm{Y}$ ). The inhibitory activity against the main protease receptor proven by the ChemPLP score is more negative than the receptor's native ligand and the comparison compounds. Jubanine B, a compound of $Z$. spina-christi has the most robust inhibition activity on the SARS-CoV-2 protease receptor. Results of this study can be concluded that this can be used to develop as a candidate for traditional medicine against SARS-CoV-2 but still it required some more in vitro and in vivo studies.
\end{abstract}

* Corresponding author

E-mail: yantih.novi@univpancasila.ac.id (Novi Yantih)

Peer review under responsibility of Journal of Experimental Biology and Agricultural Sciences.

Production and Hosting by Horizon Publisher India [HPI] (http://www.horizonpublisherindia.in/).

All rights reserved.
All the articles published by Journal of Experimental Biology and Agricultural Sciences are licensed under a Creative Commons Attribution-NonCommercial 4.0 International License Based on a work at www.jebas.org.

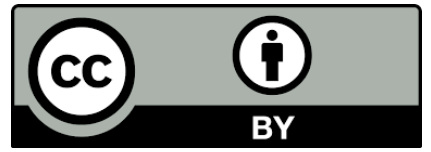




\section{Introduction}

The coronavirus disease 2019 (COVID-19) is a disease caused by severe acute respiratory syndrome coronavirus 2 (SARSCoV-2). The virus is a new type of virus in the coronavirus family that can affect the respiratory system at various levels with symptoms ranging from mild to severe (Food and Drug Monitoring Agency, Republic of Indonesia 2020; Niaz, 2020). SARS-CoV-2 is transmitted through direct contact with infected patients, droplets released by patients when coughing/sneezing, and hand touching the mouth, nose, and eyes after touching objects contaminated with the virus. The World Health Organization (WHO) has also warned of the possibility of transmission of the SARS-CoV-2 through the air for medical staff (airborne precaution for medical staff) based on a study that the coronavirus can survive in the air in certain environments (Food and Drug Monitoring Agency, Republic of Indonesia 2020).

SARS-CoV-2 is a single-stranded RNA (ribonucleic acid) enveloped virus, targeting cells through the structural protein Spike (S protein) that binds with the angiotensin-converting enzyme 2 (ACE2) receptor (Elfik, 2020). After receptor binding, viral particles use the host cell's receptors and endosomes to enter the cell. Transmembrane serine protease 2 (TMPRSS2) protein facilitates cell entry through S protein (Fehr \& Perlman, 2015). Once inside the cell, viral polyproteins encoding the replication transcriptase complex are synthesized. In this, the virus synthesized RNA via RNA polymerase which are dependent on the RNA. Structural proteins are synthesized towards the completion of assembly and release of viral particles (Fehr \& Perlman, 2015). The steps of this viral life cycle provide a potential target for drug therapy. The targets of these drug products include ACE2, S protein and TMPRSS2 (type 2 transmembrane serine protease) as well as 3-chymotrypsin like protease (3CL) a protease inhibitor (Sanders et al., 2020). 3Clike proteinase formerly known as C30 Endopeptidase is the main protease found in coronaviruses. The main protease operates at no fewer than 11 cleavage sites on the large polyprotein $1 \mathrm{ab}$ (replicase $1 \mathrm{ab}, \sim 790 \mathrm{kDa}$ ); the recognition sequence at most sites is Leu-Gln $\downarrow$ (Ser, Ala, Gly) ( $\downarrow$ marks the cleavage site). Inhibiting the activity of this enzyme would block viral replication because no human proteases with similar cleavage specificity are known (Zhang et al., 2020). The COVID-19 mechanism can be inhibited by several drug compounds including chloroquine, hydroxychloroquine, darunavir, ribavirin, arbidol, remdesivir, lopinavir and camostat mesylate (Sanders et al., 2020; Santos et al., 2020). Proteinligand docking in the drug development process predicts the complex structure of small ligands with proteins. Molecular docking yields a score proportional to the total ligand-protein binding energy. By this, comparing the scores of a compound with other compounds can explain why one compound is more potent than another. The smaller the score of a docking result means that the protein-ligand complex is more stable so that the ligand (compound) predicted is more potent (Purnomo, 2013). Through visualization, it will be seen which amino acids play an essential role in maintaining the stability of these compounds at the receptor-binding site (Purnomo, 2013; Syahputra et al., 2014; Jualiana \& Amin, 2016). In the invention of new drug compounds from natural ingredients, an in silico molecular docking test of plant compounds against target proteins is highly recommended. Since the in silico test can predict the potential of the desired plant compounds, it will save research costs and help to decide what can be tested in vitro or in vivo and which compound can serve as a potential antiviral drug. Thus, an in silico test can save the cost of drug discovery (Purnomo, 2013).

There are several natural compounds such as hesperidin, cannabinoids, pectolinarin, epigallocatechin gallate, and rhoifolin reported from various plants and have been studied insilico and have better free energy bonds with Matrix (M) and Spike (S) proteins from SARS-CoV-2 (Trina et al., 2020). It is suspected that these compounds have the potential to serve as phytochemical antivirus that can inhibit viral replication.

This research was carried out to explore new candidate compounds from $Z$. spina-christi, and $S$. ligustrine as the main protease inhibitor of SARS-CoV-2 using molecular docking. Both plants contain alkaloids, flavonoids, terpenoids, triterpenoids, steroid and phenol type compounds (Asgarpanah \& Haghighat, 2015; Maulana, 2018; Negash, 2019). Among these, alkaloid is quite dominant and this compound has properties according to the already drugs used to treat coronavirus such as chloroquine, hydroxychloroquine, darunavir, ribavirin, arbidol, remdesivir, lopinavir, camostat mesylate etc (Santos et al., 2020).

\section{Materials and Methods}

\subsection{Material}

The materials used are 5R7Y (Protein) chemical structures, chemical compounds structure of Arabic lote tree (Z. spinachristi) and snakewood (S. ligustrine). The already reported compounds of the Arabic lote tree are christinine I, christinine II, christinine III, geranyl acetate, phloretin 3',5'-di-C-glucoside, betulinic acid, cyanotic acid, quercetin 3-xylosyl-(1->2)rhamnoside, jubanine $A$, jubanine $B$, jubanine $C$, jubanine $G$, jubanine $\mathrm{H}$, amphibine $\mathrm{A}$, amphibine $\mathrm{B}$, amphibine $\mathrm{D}$, Amphibine C, amphibine E, amphibine F, amphibine G, amphibine H, amphibine I, alpha terpineol, beta-sitosterol, ziziphine F, methyl hexadecanoate, methyl octadecanoate used for in-vitro docking (Asgarpanah \& Haghighat, 2015; Maulana, 
2018; Negash, 2019). Furthermore, the already reported compounds of the tested snakewood are strychnine, brucine, strychnopentamine, malagashanine, 2,6-dimethoxyphenol, 10hydroxyusambarensine, 3-ethoxyacetophenone, 2,6-dimethyl-4nitrophenol, 2-methoxy-4-methyl phenol also used for in-vitro docking (Taek \&Tukan, 2018; Novian et al., 2019). In addition, the following compounds: Tryptamine, vincoside, 3-epistrictosidinic acid, yohimbine, reserpine, camptothecin, secologanin, 2-propanone, 1-(4-hydroxy-3-methoxyphenyl), 3methoxyacetophenone, guaiacol, n-pentanal, 4-allyl-2,6dimethoxyphenol, 19(S)-methoxytubotaiwine, 19(R)methoxytubotaiwine, dihidrocapsaicin, and ervatamine which are previously reported from snakewood also tested in the current study (Gusmailina \& Komarayati, 2015; Rale, 2018; Novian et al., 2019). The chloroquine, hydroxychloroquine, darunavir, ribavirin, arbidol, remdesivir, lopinavir, and camostat mesylate were used as comparison compounds.

\subsection{Bioinformatics Tools}

For this study YASARA, PDB, PLANTS, Marvinsketch and PYMOL software were used along with a Lenovo C9LS2ES Intel(R) Celeron(R) CPU N3060; 4 GB RAM; 1,60 GHz 64-bit operating system laptop as hardware.

\subsection{Methods}

\subsubsection{Protein Optimization and RMSD Value Determination}

Native ligands are prepared and optimized for protein crystal structure using the PLANTS program to obtain scores. The best score is selected and saved in Mol2 file format. The amount of RMSD poses of the optimization results regarding the experimental results or protein crystal structure is calculated with the YASARA program.

\subsubsection{Test and comparator ligand docking against receptor}

In this, docking is carried out between each test compound ligand using the PLANTS program. The docking runs by typing the script into the CMD worksheet to determine the target protein's binding-site radius and binding-site centre. The docking process runs automatically by plantconfig protocol. The molecular docking set was determined in 10 replications with 10 confirmations to locate and determine the lowest amount of energy (Tegar \& Purnomo, 2013). The best score of test compound ligand is obtained from the result of docking. This value will be compared with the best score of the comparator compound ligand.

\subsubsection{Visualization}

Docking results file making from each test compound ligand is with the YASARA program (PDB file type). This docking result file will be visualized and interpreted to determine the interactions that occur using the PyMOL application.

\section{Results and Discussion}

The main protease protein's crystal structure in the docking process is a protein that was validated and complied with the RMSD requirements of less than $2 \AA$ (Rangwala \& Karypis, 2008). $5 \mathrm{R} 7 \mathrm{Y}$ met the RMSD requirement for native ligand pose and the redocking pose was $1.4829 \AA$ in the redocking process. The molecular docking with RMSD of less than $2 \AA$ meant that the position of ligand that bound to the protein's active side did not move too far since the conversion from $2 \AA$. The range size is equal to $0.2 \mathrm{~nm}$ corresponded to that of an atom's diameter which is about $0.1 \mathrm{~nm}$.
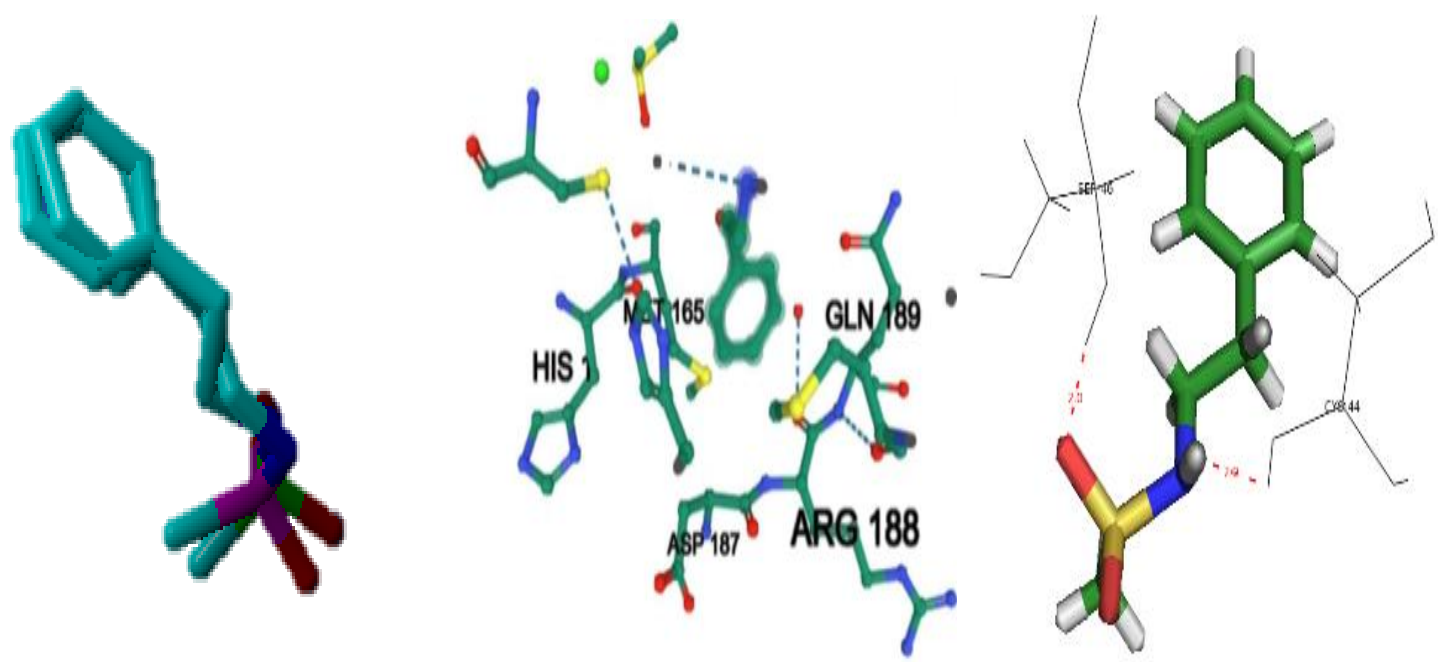

Figure 1 Superimpose of native ligand pose and the redocking native ligand pose and its residues amino acid interactions

Journal of Experimental Biology and Agricultural Sciences

http://www.jebas.org 


\subsection{Docking Results Analysis}

There are 27 compounds of Z. spina-christi, and 26 compounds of $S$. Ligustrine were tested for their affinity as protease inhibitors against the $5 \mathrm{R} 7 \mathrm{Y}$ receptor. All these compounds were tested in silico using the molecular docking method. The docking process was carried out at the binding site of the $5 \mathrm{R} 7 \mathrm{Y}$ receptor and the ChemPLP score was calculated for each compound pose in the active site. ChemPLP score showed Gibbs free energy in which the smaller the $\Delta \mathrm{G}$ value of the ligand-receptor interaction, the more stable it would be. The more negative ChemPLP score of the tested compound means stronger affinity at the receptor-binding site (Kurniawan, 2015). Table 1 represented the ChemPLP score of all compounds in the binding site of the receptor 5R7Y. It showed that all ligands have a more negative score than the native ligand (JFM), which means that all test compounds are predicted to have a better affinity than the native ligand. It can be explained that all the comparison compounds have inhibition activity on SARS$\mathrm{CoV}-2$ replication (in its antiviral role).
The ChemPLP score of all the test compounds of Z. spina-christi are smaller than the used native ligand. Further, the results also showed that among the tested 27 compounds of $\mathrm{Z}$. spina-christi, ChemPLP score of 4 (four) alkaloid peptides compounds namely Jubanine B, Jubanine C, Amphibine E, and Amphibine $\mathrm{H}$ had a smaller ChemPLP value than the positive control (darunavir) Mauludiyah et al. (2020). Meanwhile, none of the 26 test compounds derived from S. ligustrine showed stronger affinity than the same comparator (darunavir). However, among these, there are 16 compounds were reported active because their ChemPLP scores were more negative than the native ligand.

Of the 53 compounds tested, none were had predicted to have a better or equal affinity to the remdesivir in inhibiting SARS-CoV2, while the Jubanine B compound of $\mathrm{Z}$. spina-christi leaves had a predicted strong activity because the ChemPLP was more negative than lopinavir in inhibiting the SARS-CoV-2 receptor. Additionally, this compound also had stronger activity in inhibiting the SARS-CoV-2 protease receptor. Based on this, it can be

Table 1 ChemPLP Score of the used compounds

\begin{tabular}{|c|c|c|c|c|c|c|}
\hline $\begin{array}{l}\text { S. } \\
\text { No }\end{array}$ & Compounds & $\begin{array}{l}\text { ChemPLP } \\
\text { Score }\end{array}$ & Compounds & $\begin{array}{l}\text { ChemPLP } \\
\text { Score }\end{array}$ & Compounds & $\begin{array}{l}\text { ChemPLP } \\
\text { Score }\end{array}$ \\
\hline \multicolumn{3}{|c|}{ Comparison compounds } & \multicolumn{2}{|l|}{ Z. spina-christi } & \multicolumn{2}{|l|}{ S. ligustrine } \\
\hline 1 & $\begin{array}{l}\text { JFM } 1001 \text { (Native } \\
\text { Ligand) }\end{array}$ & -64.492 & Geranilasetat & -67.4666 & Strychnine & -70.159 \\
\hline 2 & Klorokuin & -81.267 & Christinin I & -69.3772 & Brucine & -72.5403 \\
\hline 3 & Hidroksiklorokuin & -83.189 & Christinin II & -72.3141 & Strychnopentamine & -88.2194 \\
\hline 4 & Darunavir & -96.741 & Christinin III & -75.5299 & Malagashanine & -65.5535 \\
\hline 5 & Ribavirin & -66.8404 & $\begin{array}{l}\text { Phloretin } 3^{\prime}, 5^{\prime} \text {-Di-C- } \\
\text { glucoside }\end{array}$ & -87.2636 & 2,5-Dimethoxybenzyl alcohol & -54.8569 \\
\hline 6 & Arbidol & -83.9751 & Betulinic acid & -69.9086 & 2,6-Dimethoxyphenol & -55.4956 \\
\hline 7 & Remdesir & -113.848 & Ceanothic acid & -74.2428 & 10-hydroxyusambarensine & -81.8363 \\
\hline 8 & Lopinavir & -110.28 & $\begin{array}{l}\text { Quercetin 3-xylosyl }(1,2) \\
\text { rhamnoside-4'rhamnoside }\end{array}$ & -81.8981 & 2,6-Dimethyl-4-nitrophenol & -55.5903 \\
\hline 9 & Camostat mesylate & -90.2515 & Jubanine A & -102.689 & 2-methoxy-4-methylphenol & -55.2316 \\
\hline 10 & & & Jubanine B & -110.367 & 3-Ethoxyacetophenone & -58.5119 \\
\hline 11 & & & Jubabine $\mathrm{C}$ & -105.471 & Tryptamine & -57.6537 \\
\hline 12 & & & Jubanine $\mathrm{G}$ & -88.9747 & Vincoside & -88.9451 \\
\hline 13 & & & Jubanine $\mathrm{H}$ & -89.2483 & 3-epi-Strictosidinic acid & -86.5313 \\
\hline 14 & & & Amphibine A & -101.716 & Yohimbine & -77.8269 \\
\hline 15 & & & Amphipine B & -100.539 & Reserpine & -65.3186 \\
\hline 16 & & & Amphibine $\mathrm{C}$ & -99.0982 & Camptothecin & -67.3791 \\
\hline 17 & & & Amphibine D & -100.103 & Secologanin & -73.5241 \\
\hline 18 & & & Amphibine E & -104.13 & $\begin{array}{l}\text { 2-Propanone, 1-(4-hydroxy-3- } \\
\text { methoxyphenyl) }\end{array}$ & -60.3211 \\
\hline 19 & & & Amphibine $\mathrm{F}$ & -90.6102 & 3-Methoxyacetophenone & -55.4328 \\
\hline 20 & & & Amphibine $\mathrm{G}$ & -96.5544 & 19(R)-methoxytubotaiwine & -67.0108 \\
\hline 21 & & & Amphibine $\mathrm{H}$ & -103.514 & 19(S)-Methoxytubotaiwine & -65.6651 \\
\hline 22 & & & Amphibine I & -89.4811 & Dihidrocapsaicin & -80.3741 \\
\hline 23 & & & zizyphine $\mathrm{F}$ & -94.1967 & Ervatamine & -72.5855 \\
\hline 24 & & & Alpa terpineol & -61.3281 & Guaiacol & -52.9905 \\
\hline 25 & & & Beta sitosterol & -84.8232 & n-Pentanal & -44.4185 \\
\hline 26 & & & Methyl hexadecanoate & -78.6953 & 4-Allyl-2,6 -dimethoxyphenol & -75.4356 \\
\hline 27 & & & Methyl octadecanoate & -83.5505 & & \\
\hline
\end{tabular}

Journal of Experimental Biology and Agricultural Sciences

http://www.jebas.org 
suggested that $Z$. spina-christi can be used as a candidate for raw material in traditional drugs against SARS-CoV-2 antivirus. Further studies are required to standardize the in vitro and in vivo potential of $Z$. spina-christi extracts against SARS-CoV-2.

\subsection{Visualization of Ligand - Protein Interaction}

Compound visualization at the binding site is depicted in threedimensional (3D) form so that it can visualize the amino acids involved in the active compound affinity with the SARS-CoV-2 protease enzyme, and determine the hydrogen bond distance in angstrom $(\AA)$ units between the candidate drug compounds and amino acids existing between the SARS-CoV-2 protease enzyme receptor $(5 \mathrm{R} 7 \mathrm{Y})$. The visualisation results of the four protease inhibitor candidate compounds can be seen in Figure 2.
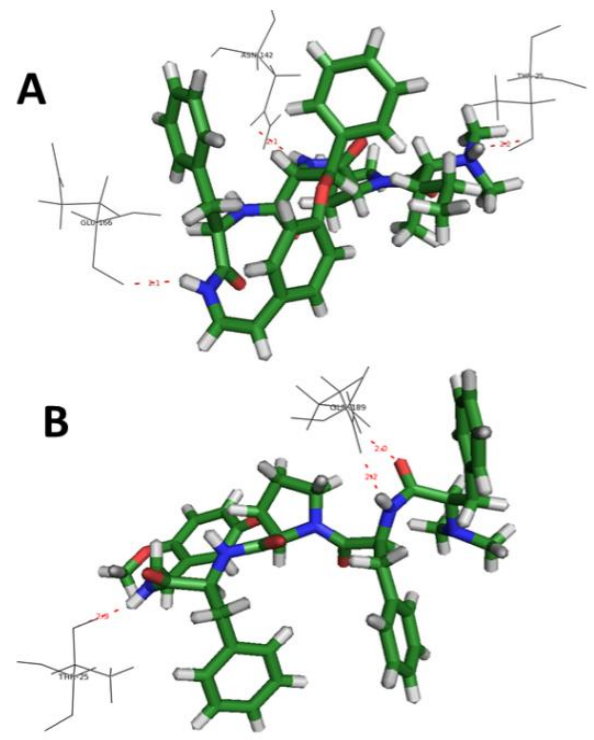

Figure 2 Visualisation result of the candidate protease inhibitor compound at 5R7Y receptor A) Jubanine C; B) Jubanine B;

C) Amphibine H ; D) Amphibine E

Table 2 Amino acids residue obtained in 5R7Y receptor binding

\begin{tabular}{|ccc|}
\hline Compound Name & Amino acid & Bond distance $(\AA)$ \\
\hline Jubanine B & THR-25 & 2.1 \\
& GLN-189 & 1.9 \\
\hline & THR-25 & 2.2 \\
Jubanine C & GLU-166 & 2.1 \\
& ASN-142 & 2.1 \\
\hline & GLN-189 & 2.1 \\
\hline & GLY-143 & 2.1 \\
& ASN-142 & 1.9 \\
\hline
\end{tabular}

Journal of Experimental Biology and Agricultural Sciences http://www.jebas.org 


\section{Conclusion}

The Jubanine B compound of Z. spina-christi has the most robust inhibition activity on the SARS-CoV-2 protease receptor and after some detailed study, it can be used as a candidate for traditional antiviral medicine against SARS-CoV-2.

\section{Acknowledgement}

Special thanks to Kemenristek-BRIN for funding this research (Grant Number: 99/LL3/PG/2020).

\section{Conflict of Interest}

The authors declare no conflict of interest.

\section{References}

Asgarpanah J, Haghighat E (2015) Phytochemistry and pharmacologic properties of Ziziphus Spina-Christi (L.) Willd. African Journal of Pharmacy and Pharmacology 6(31): 2332 2339.

Berry M, Fielding B, Gamieldien J (2015) Practical considerations in virtual screening and molecular docking. In: Tran QN, Arabnia $\mathrm{H}$ (Eds), Emerging trends in computational biology, bioinformatics, and systems biology. Elsevier Inc. https://doi.org/10.1016/B978-0-12-802508-6.00027-2.

Elfik AA (2020) Anti-HCV, nucleotide inhibitors, repurposing against COVID-19. Life Sciences 248(5):6. https://doi.org/ 10.1016/j.lfs.2020.117477.

Fearo D, Powell AJ, Douangamath A, Owen CD, Wild C, Krojer T, Lukacik P, Strain-Damerell CM, Walsh MA, von Delft F (2020) PanDDA analysis group deposition-crystal structure of COVID-19 main protease in complex with Z45617795. https://doi.org/10.2210/pdb5R7Y/pdb

Fehr AR, Perlman S (2015) Coronaviruses: an overview of their replication and pathogenesis. Methods in Molecular Biology 1282(1): 1 - 23. doi: 10.1007/978-1-4939-2438-7_1.

Food and Drug Monitoring Agency, Republic of Indonesia (2020) Covid-19 drug information in Indonesia, Jakarta, available at http://online.flipbuilder.com/tbog/infi/mobile/index.html Retrieved on April 22, 2021,

Gusmailina \& Komarayati KS (2015) Potential exploration of snakewood (Strychnos lucida) organic compounds as a biopharmaceutical source. National Seminar Process of Indonesian Biodiversity Society 1(7):1741 - 1746.
Jualiana K, Amin M (2016) Development of textbooks for cell biology courses with bioinformatics approach for undergraduate students of Malang State University. Educational, Theory, Research and Development Journal 1(9):1677- 1683.

Kurniawan SN (2015) Neuronal signaling. Malang Neurology Journal 1(2):86-96.

Maulana M (2018) Thin layer chromatography (TLC) profile of arabiclote tree leaf extract (Ziziphus spina-christi L.) based on solvent variation (Mini Thesis). Malang: Faculty of Science and Technology, Maulana Malik Ibrahim Islamic State University, Pp.10-11.

Mauludiyah EN, Fitrianti D, Gita CED (2020) Phytochemical screening of secondary metabolite compounds from simplicia and water extract of arabic bidara (Ziziphus Spina-Christi L.) leaves. Seminar Penelitian Sivitas Akademika Unisba 6 (2):https://doi.org/10.29313/.V6i2.24325

Negash L (2019) Ziziphus spina-christi ( L.) Desf. (Rhamnaceae).In: A selection of Ethiopia's indigenous trees: biology, uses, and propagation techniques, Addis Ababa University Press, Ethiopia, Pp. 334.

Niaz A (2020) Remdesivir \& chloroquine can effectively inhibit the recently emerged novel coronavirus (2019-NCOV) in vitro. Cell Research 30 (1): 269-271. https://doi.org/10.1038/s41422020-0282-0

Novian DR, Ikhwani AZN, Winarso A (2019) Tests of pharmacodynamic, drug-likeness, pharmacokinetic and interaction of snakewood (Strychnos lucida) active compound as in silico Plasmodium falciparum inhibitor. Archipelago Veterinary Journal 2(1):78.

Purnomo H (2013) Computational chemistry for pharmacy and science related to in silico test and anticancer compounds, $1^{\text {st }}$ ed. Yogyakarta: Student Library, Pp.210.

Rale SD (2018) Antioxidant and in vitro activity of alphaglucosidase inhibition of snakewood (Strychnos nitida G. Don) trunk ethanol extract and identification of active compounds. Thesis submitted to the Graduate School of Bogor Agricultural Institute h.1-2.

Rangwal H, Karypis G (2008) RMSD Pred: predicting local RMSD between structural fragments using sequence information. Proteins 72 : 1005-18.

Sanders JM, Monogue ML, Jodlowski TZ, Cutrell JB (2020) Pharmacologic treat for coronavirus disease 2019 (COVID-19). JAMA Network doi:10.1001/jama.2020.6019 
Santos J, Brierley S, Gandhi MJ, Cohen MA, Moschella PC, Tegar M, Purnomo H (2013) Tea leaves extracted as anti-malaria Declan ABL (2020) Repurposing therapeutics for potential based on molecular docking PLANTS. Procedia of Environmental treatment of SARS-CoV-2: a review. Viruses 12 (7): 705; Science 17: 188 - 94.

https://doi.org/10.3390/v12070705

Syahputra G, Ambarsari L, Sumaryada T (2014) Docking simulation of enol curcumin, bis-demethoxy curcumin and its analog as 12-lipoxygenase enzyme inhibitor. Biophysics Journal 10(1): $55-67$.

Taek M, Tukan G (2018) Antimalarial activity of snakewood extract (Strychnos ligustrina) in mice infected with Plasmodium berghei. Natural Science Sains 1(3): $1-2$.
Trina TE, Sefren TG, Nurdjannah NJ, Fatimawali, Billy KJ, Idroes R, et al. (2020) Potential of plant bioactive compounds as SARSCov-2 main protease (Mpro) and spike (S) glycoprotein inhibitors: a molecular docking study. Preprints 2(2):1-18.

Zhang L, Lin D, Sun X, Curth U, Drosten C, Sauerhering L, Becker S, Rox K, Hilgenfeld R (2020) Crystal structure of SARS$\mathrm{CoV}-2$ main protease provides a basis for design of improved $\alpha$ ketoamide inhibitors. Science 368 (6489):409-412. https://doi.org/ 10.1126/science.abb3405. 